\title{
THE CONCEPTUAL ASPECTS OF VOCATIONAL FOREIGN LANGUAGE STUDYING
}

\author{
Yana Necheporuk ${ }^{1}$ \\ ${ }^{I}$ Ph.D. (Pedagogy), doctoral student of Pedagogy and education management department, Volodymyr \\ Vynnychenko Central Ukrainian State Pedagogical University, Kropyvnytskyi, Ukraine, e-mail: \\ yananecheporuk83@gmail.com,ORCID: https://orcid.org/0000-0003-1152-8030
}

\begin{abstract}
The pedagogical process is constantly enriched with new ways of operating the received information, a creative approach to solving science issues with an emphasis on the individualization of educational programs. This applies to the aviation industry as well. In their professional activity pilots do not have complete information about the people with whom they communicate. Unforeseen air situations often occur, and the pilot does not have accurate information about who he is communicating with, who is controlling the air traffic, and what his further actions and decisions are related to. In extreme situations, when time is counted in seconds, knowledge of technical terms and concepts in English allows you to correctly report an obvious or emergency situation, to make a timely and correct decision. The main trends in the improvement of educational technologies are characterized by the transition from the focus on the average student to individualized training programs. In such conditions, the teacher, who performs the function of a «technologist» of the educational process, needs to use innovative technologies, ideas, directions.

The article describes the methods of teaching students who study in higher aviation educational institutions. The specifics of teaching subjects in English are determined in accordance with learning strategies. English, chosen as the main means of teaching students, causes changes in the methodological support of the educational process. In view of this, it is appropriate to add that the specifics of the organization in relation to the learning process in a multicultural environment should be taken into account. In this regard, we analyze some conceptual methods that help increase the level of methodological support for training and the quality of vocational training.
\end{abstract}

Keywords: Aviation, specialist, foreign language, training, vocational studying.

JEL Classification: I0; I20

Formulas: 0; fig.: 0; tabl.:0, bibl.:11

Introduction. Ukraine has chosen a course of entering the European educational space. Integration with European countries, internationalization of business relations in various spheres of human activity increases the demand for competent specialists who are capable to solve professional issues in both native and foreign languages.

The changes in a field of education also raise the issue of using foreign language in future professional activities. We also have to optimize the search for ways of improving the training of future foreign language professionals as a means of professional communication that should promote their mobility and competitiveness on a labor market, to ensure the formation of a high level of professionalism.

Literature Review. The problem of readiness to use a foreign language in professional activities has been deeply developed in modern pedagogy. Based on the analysis of scientists' research concerning vocational foreign language (O. Bernatska, V. Volkova， L. Golikova， R. Grishkova， L. Dariychuk， N. Zamkova， S. Isaenko, L. Kadchenko, M. Knyazyan, S. Kozak, O. Litikova, I. Mezhuyeva, A. Melnyk) and professionally oriented foreign language communication (R. Buzhikov, M. Halytska, L. Gaponenko, L. Dariychuk, Y. Druz, V. Piven, N. Sura) found that knowledge of a foreign language is determined by an important factor in forming the personality of a 
modern specialist and one of the components of his training. At the same time, it was found that most of the above studies are devoted to increase the level of readiness to use a foreign language in the professional activities of economists, lawyers, managers, teachers, specialists in tourism, military and some other fields. So, there is still the open space for researches in the sphere of foreign language training for aviation specialists.

Aims. For aviation professionals, English becomes a mechanism for studying the content of relevant documents; language learning is not considered as an auxiliary part of training, and as an integrated component of all aviation training. The function of an aviation specialist is that he must be able to describe, request, confirm and clarify information through communication skills [5, p.236].

According to item 1.2.9.4. Amendments 164 to Annex 1 Personnel Licensing (Doc 9835-AN / 453 Manual on the Implementation of the ICAO Language Proficiency Requirements, 2004) adopted by the International Civil Aviation Organization (ICAO) on 27 November 2003, starting on 5 March 2008, airplane and helicopter pilots, air traffic controllers and airline operators must be able to communicate in English and understand it at the fourth working level out of six defined (the fourth level is the minimum sufficient for the language support of the flight on international air routes). The working level involves effective communication in general, specific and work-related topics. The appearance of these documents is the result of an analysis of aviation incidents, one of the reasons for which was insufficient for the performance of functional duties by employees of the industry level of English language proficiency. Thus, proficiency in English became significant for aviation specialists, as it is an obligatory for flights security on international routes, as defined by ICAO for all countries [11].

Ukraine is one of the few countries that has its own aviation industry complex and can be competitive in this field. It is important for the domestic economy not to lose this position. Higher educational institutions are interested in training modern skilled aviation specialists capable of developing aircraft and rocketry in Ukraine. So, for successful execution In this task, domestic future specialists must improve their theoretical and practical knowledge not only professional disciplines, but also a foreign language and master a number of skills.

Methods. The peculiarity of language learning is that it must be focused on studying in context and on its use in real communication and professional activities. Thus, to achieve this goal, students must acquire knowledge of a foreign language communicative competence, which is a sign of professional competence. Special attention must be paid on adaptation of educational materials for students of a certain technical field. Materials must be considered to the needs and interests of students, focus on relevant topics and contain tasks that aimed at training and improving the necessary knowledge and skills [6, p.123].

The development of information technology contributes to the emergence of electronic resources that are possible to use and improve the lexical competence of future aviation specialists. Aviation professionals can use NASA's thesaurus, which was created for optimization of aerospace research processes 
(https://www.sti.nasa.gov/nasathesaurus). WordNet is used as a standard for creating lexical-semantic databases. Today, dictionaries compiled according to WordNet are a popular lexical resource. They combine the features of a reference book and a resource that provides an opportunity to conduct linguistic research. WiKi services also allow you to create dictionaries. This type of activity can be performed collectively, involving students. Materials can be updated, supplemented, edited, expanded with the help of graphic material. All materials can have cross-references. This can stimulate students to develop professional vocabulary, to search new terms and use the in process of English language learning [8, p.37].

According to the curriculum, the process of vocational language studying consists of practical and self-studying parts. Effective organization of self-studying work and well-chosen materials can help to form the lexical competence of aviation students. Distance courses that have been introduced into the learning process are an effective tool to achieve a goal. This technology allows to develop tasks for mastering professional vocabulary, applying the principle of clarity, to involve students in compiling terminological vocabulary, to bring the use of terms to automatism. [2, p.17]. This type of work significantly increases motivation of students by increasing their self-confidence and knowledge, creating favorable conditions and developing exercises that diversify the learning process, opportunities to improve their results and review the results of work. The process of cognitive activity (thinking) and development of memory and attention promote the acquisition of lexical material.

Results. First of all, in our opinion, it should be determined the difference between the concepts of «foreign language» and «second language». A foreign language is a language which is studied outside its natural existence, during the educational process and which is not used with the native language in everyday communication. A «second language» serves as a second means of communication and is learned in the social environment where it is a real means of communication Thus, a foreign language, in contrast to the «second language», is mastered a person outside the social environment in which this language is a natural remedy communication.

According to the common definition of learning process structure we believe that learning a foreign language is a complex process that combines two types of activities: teaching and learning. The subject of the first is a teacher who systematically, consistently transfers knowledge to students and develops their practical skills. The subject of learning a foreign language is a student who is active and conscious acquires knowledge, skills and abilities.

The concepts of «language learning» and «language acquisition» are not identical. W. Edmondson and J. House believe that the process of language acquisition is unconscious, intuitive language acquisition during the socialization between individuals [9, p.11].

The process of learning a language is conscious, involves the usage and mastering the rules, language elements. Thus, the meaning of the concept of 
«language learning» is broader than the meaning of the concept of «mastery of language».

In modern conditions, foreign language learning is considered in three aspects: pragmatic (practical), cognitive and educational. Pragmatic aspect of foreign language learning means the formation of a certain set of knowledge, skills and abilities, the set of which allows to be a successful participant of foreign language communication. The cognitive aspect considers foreign language learning as means of intercultural communication and its intensive use as a means of language cognition and development; the general educational aspect considers the foreign language teaching as an educational action that is concentrated on the personality of the learner.

This aspect concerns the formation of personal qualities that contribute to the mastery of foreign language and its practical use as a means of engaging in another culture and means of communication with its carriers. Ability to communicate at the intercultural level provides for the presence of a future specialist in the aviation industry such personal qualities such as openness, tolerance and willingness to communicate [10, p.129].

Thus, the purpose of learning a foreign language is to develop the ability in the future bachelors in avionics to intercultural communication, by which we mean mutual understanding between the participants of a communicative act belonging to different national cultures. The purpose of learning a foreign language, in our opinion, is an integrative concept, which consists of personal qualities: intelligence, attention, memory, interest in educational and cognitive activities, the ability to see, understand and accept common and different in different national cultures, the ability to social interaction, readiness to use a foreign language as a means of communication with native speakers, tolerance. They are all interconnected and interdependent.

Underestimation or overestimation of one aspect of foreign language learning can negatively affect the quality of vocational language knowledge as a mean of intercultural communication. Ability of oral communication, which relates to the sphere of social relations between people, directly related to the personal qualities of the learners. These personal allow future aviation professionals to interact effectively with each other. It should be noted, that the success of foreign language communication in aviation sphere depends on the General English level, the ability to communicate in different situations.

As noted by scientists Kharlamova L.S. and Chala N.D. the biggest problem in interactive methods usage while studying foreign language is the passivity of students. Due to their emotional tightness, students are afraid to express their own opinion. He/She has an irresistible fear of the audience, fear of being criticized for mistakes. The task of a teacher, with the help of different interactive techniques, to unleash the potential in each individual, improve communicative skills of students. It is the creation of a comfortable situation under time of business games, creation creative projects, discussion, promotes the formation of communication skills [3, p.212]. 
The interactive approach as a kind of communicative approach in the teaching of aviation English, according to the recommendations of ICAO, is implemented through the following activities during the lesson:

- exercises for interactive listening, which encourage oral answers during the hearing;

- exchange of information in class and role activities (pilot-ATC controller);

- working out vocabulary and grammatical structures through oral exercises, not through reading and writing;

- use of graphic (oscilloscope, control panel, maps) and digital (tables and displays) data to create situational real working conditions of the pilot and dispatcher;

- creating problem situations and solve them in groups [5, p.235].

Given that the system of foreign language education is one of subsystems of the general education system, the knowledge of a foreign language by future professionals has an economic justification. Socio-economic and political factors determine the social order of the foreign language level and its quality. Social order is expressed by prestige or non-prestige of foreign language knowledge by professional in different technical spheres. The higher these needs, the higher the foreign language status as a mean of communication and a component of professional suitability.

Socio-economic and political factors not only shape the social order of society regarding foreign language learning, but also create favorable conditions for its implementation.

Discussion. Based on experience in training future specialists in aviation before carrying out their future professional activity it better to offer while reading not to make a literal translation of the text; it is appropriate to refer to their life experience; perform contextual translation of unfamiliar words using reference tools available in the text (diagrams, figures, tables, keywords) [1, p.78]. We believe that it is advisable to refer to the dictionary only when students are out of possibilities to understand the meaning of the word. However, working with technical documentation requires accurate translation based on a thorough knowledge of aviation terminology. The process of foreign language reading includes work on reading technique and development ability to understand the content of what is read.

There are didactic and specialized principles that reflect the basic approaches related to vocabulary learning and its successful acquisition. Consciousness, the principle of clarity, interdisciplinary connections, professional orientation, the use of all types of speech activities are the main factors through which students are able to master professional vocabulary [3, p.126].

The principle of professional orientation is embodied through the use of professional educational materials. The authentic text remains the main source for studying and getting acquainted with the terms. Reading professionally-oriented texts is considered as one of the methods of professional vocabulary formation. Working on technical texts, students learn new vocabulary, understand the meaning of the term due to the context, expand vocabulary [7, p.69].

Conclusion. For the professional development of the future pilot in the training process of professionally oriented English requires the formation of translation skills, 
understanding professional literature and communication skills in professionally oriented English language in situations of a professional nature. Motivation for professional communication in English plays an important role in pilots' professional activities. One of the priority teachers' tasks in flight schools is the formation of motivation for professional communication in English language in future aviation specialists.

It is important to substantiate the pedagogical conditions that would help to increase the level of motivation for professional communication during the process of vocational English learning. The analysis of different foreign language approaches and methods made it possible to single out the interactive approach as one of the most effective, which involves the active participation of cadets, promotes cooperation and significantly increases the motivation for the learning process, can be effective in the process of professional training of pilots. The use of interactive teaching methods such as business games, educational discussions, presentations, modeling of problem situations and situations of professional character, performance of exercises of various type, discussion video plots have practical significance, they can be constructively applied in pedagogical practice during the process of future pilots' training.

\section{References:}

1. Barabanova, G.V. (2005), Metodyka navchannia profesiino-orientovanogo chytannia v nemovnomu VNZ [Methods of Teaching of Professionally-Oriented Reading in the Nonlinguistic Higher Educational Institutions], INKOS, Kyiv, Ukraine.

2. Biretska, L.S. (2014), Vpravy dlia formuvannia anhlomovnoi leksychnoi kompetentnosti maibutnikh likariv u profesiino oriientovanomu chytanni [English lexical competence formation tasks for future doctors in professional reading]. Inozemni movy, 3 (79), Kyiv, Ukraine.

3. Kharlamova, L.S., Chala, N.D., Kovaleva, I.V. (2020), Modern technologies of teaching foreign languages in technical higher institutions. Scientific Bulletin of the Flight Academy. Series: Pedagogical sciences, 7. Retrieved 12.07.2020 from http://ksgn.hol.es/wpcontent/uploads/2017/04/33-1.pdf. (in Ukr.).

4. Melnikov, M.V. (2016), Formirovanie rechevoi kompetentnosti budushhikh inzhenerov na osnove polimodal'nogo predctavleniya uchebnogo materiala $v$ protsesse profeccional'noi pidgotovki [The formation of speech competence of future engineers on the basis of a multimodal representation of educational material in the process of professional training], Extended abstract of candidate's thesis, Ulyanovsk, Russia.

5. Moskalenko, O.I. (2020), Humanitarna pidhotovka maybutnikh fakhivtsiv aviatsiynoyi haluzi iz vykorystannyam innivatsiynykh tekhnolohiy [Humanitarian preparation of future aviation specialists by means of innovative technologies], Cherkassy, Ukraine.

6. Semenchik, Yu.O. (2006), Psykholoho-pedahohichni peredumovy formuvannia leksychnoi kompetentsii u studentiv ekonomichnykh spetsialnostei [Psychological and pedagogical prerequisites of lexical competence formation of students of economic specialties], Psykholohiia i suspilstvo, 4.

7. Tarnopolskii, O.B. (1999), Project English dlya povysheniya effektivnosti obucheniya angliiskomu yazyku vo vzrosloi auditorii [Project English for increasing the efficiency of teaching English at an adult audience], In Innovatsiini pidkhody do vykladannia inozemnykh mov (pp.193-196), Dnipropetrovsk, Ukraine.

8. Vadanska, S.V. (2017), Osoblyvosti formuvannya inshomovnoi kompetentnosti studentiv v galuzi avia ta raketobuduvannya [Students' lexical competence formation in the field of air and rocket building.], Kyiv, Ukraine.

9. Edmondson, W., House, J. (1993), Einfuerung in die Sprachlehrfor-schung. Tuebingen; Basel: Francke, $341 \mathrm{~S}$.

10.Handbuch. Fremdsprachenunterricht / hrsg. von K.-R. Bausch u. a. Tuebingen, France, 1989, 495 S.

11.Doc 9835-AN/453 Manual on the Implementation of the ICAO Language Proficiency Requirements, Preliminary edition, 2004, 162 c. 